\title{
Influence of a supplement containing conjugated linoleic acid on dairy performance, milk fatty acid composition, and adipose tissue reactivity to lipolytic challenge in mid-lactation goats
}

\author{
S. Ghazal, ${ }^{*} \dagger$ V. Berthelot, ${ }^{*} \dagger$ N. C. Friggens, ${ }^{*} \dagger$ and P. Schmidely ${ }^{*}{ }^{1}$ \\ ${ }^{*}$ AgroParisTech, UMR791 Modélisation Systémique Appliquée aux Ruminants, 16 rue Claude Bernard, F-75005 Paris, France \\ †INRA, UMR791 Modélisation Systémique Appliquée aux Ruminants, 16 rue Claude Bernard, F-75005 Paris, France
}

\begin{abstract}
The objective of this work was to evaluate the effect of the supplementation of conjugated linoleic acid (CLA; $4.5 \mathrm{~g}$ of cis-9,trans-11 C18:2 and $4.5 \mathrm{~g}$ of trans-10, cis-12 C18:2) on milk performance, milk fatty acid (FA) composition, and adipose tissue reactivity in dairy goats fed a high-concentrate diet based on corn silage. Twentyfour multiparous dairy goats in early to mid lactation were used in a 10 -wk trial, with a 3 -wk adaptation to the experimental total mixed ration that contained corn silage (35\%, dry matter basis), beet pulp (20\%), barley $(15 \%)$, and a commercial concentrate $(30 \%)$. Goats were randomly allocated to 2 experimental groups and they were fed $45 \mathrm{~g} / \mathrm{d}$ of a lipid supplement (either CLA or Ca salts of palm oil added on top of the total mixed ration). Individual milk production and composition were recorded weekly, and milk FA composition was analyzed in wk 2,5 , and 6 . In the last week of the trial, an isoproterenol challenge was performed for 12 goats before morning feeding. The CLA supplementation had no effect on dry matter intake (DMI), body weight (BW), milk yield, milk protein content, and lactose yield and content, but it significantly decreased milk fat yield and content by 18 and $15 \%$, respectively. The decrease in milk fat yield was related to a lower secretion of FA synthesized de novo, of the medium-chain FA, and to a lesser extent of the long-chain FA that are taken up from the peripheral circulation. The CLA supplementation decreased the proportion of the sum of $\mathrm{C} 16: 0$ and $\mathrm{C} 16: 1$ and the sum of total cis C18:1, and it increased the proportions of the sum of long-chain $(\mathrm{C}>16)$ and the sum of iso FA without modification of the total trans C18:1 and the sum of FA synthesized de novo $(\mathrm{C}<16)$. During the first $25 \mathrm{~min}$ relative to isoproterenol injection, the maximal concentrations, the increases above basal concentration, the changes in area under the curve, and the total area under the curve
\end{abstract}

Received June 5, 2012.

Accepted September 1, 2012.

${ }^{1}$ Corresponding author: philippe.schmidely@agroparistech.fr for glucose and nonesterified FA were not affected by CLA treatment. In conclusion, CLA supplementation associated with a high-concentrate diet based on corn silage resulted in decreased milk fat yield, increased net energy balance, and it did not affect the sensitivity of the adipose tissue to lipolytic challenge in lactating goats.

Key words: conjugated linoleic acid, milk fatty acid composition, lipolytic challenge, goat

\section{INTRODUCTION}

Conjugated linoleic acids (CLA) are geometric and isomeric isomers of linoleic acid that are produced during ruminal biohydrogenation of linoleic acid (Lourenço et al., 2010). Conjugated linoleic acids are mainly produced when high levels of PUFA and high percentages of rapidly fermentable carbohydrates are associated (Bauman et al., 2003). Among the CLA isomers, the trans-10, cis-12 C18:2 isomer is known to be the most potent isomer for decreasing milk fat content (MFC) in dairy cows (Baumgard et al., 2000), even if cis10,trans-12 and trans-9,cis-11 isomers induce similar responses (Sæbø et al., 2005; Perfield et al., 2007). Molecular-based approaches indicated that trans-10, cis-12 C18:2 simultaneously downregulated the abundance of transcript of key genes involved in de novo synthesis of FA, uptake of long-chain FA, and desaturation of FA in the mammary gland of cows (Shingfield et al., 2010; Bauman et al., 2011). In dairy goats, feeding ruminally protected trans-10, cis-12 C18:2 resulted in a smaller decrease in MFC than in cows (Lock et al., 2008; Shingfield et al., 2009), reflecting a lower sensitivity of the goat mammary gland to the antilipogenic effect of trans-10, cis-12 C18:2.

It has been shown that the stage of lactation, the duration of the trial, and the form of protection of dietary trans-10,cis-12 C18:2 affect the response of mammary gland to CLA supplementation (Bauman et al., 2008) but less attention has been paid to diet composition. In cows (de Veth et al., 2006) and in ewes (Weerasinghe et al., 2012), CLA may alter partitioning 
of nutrients to support an increase in milk and protein yield when dietary energy is limited. Moreover, feeding CLA to dairy cows fed a high-concentrate diet (high starch-low NDF) resulted in a smaller decrease in MFC than in cows fed a low-concentrate diet (low starch-high NDF), suggesting that dietary ingredients or diet composition (or both) may affect the response or sensitivity of the mammary gland to trans-10,cis-12 C18:2 (Glasser et al., 2010). In dairy goats, reduced MFC was observed with a low-concentrate-low-starch diet based on alfalfa hay (Shingfield et al., 2009), and with a high-concentrate diet based on hay (Lock et al., 2008) during short-term trials. To date, no information is available on the response to trans-10,cis-12 C18:2 of dairy goats fed high-concentrate diets based on corn silage during a long-term trial.

In opposition to changes observed in the mammary gland, expression of lipogenic enzymes and of genes related to lipid synthesis in subcutaneous adipose tissue were increased during short-term trans-10, cis-12 C18:2 supplementation in cows (Harvatine et al., 2009), reflecting the partitioning of spared energy away from milk toward adipose tissue. Simultaneously, von Soosten et al. (2011) reported reduced mobilization of retroperitoneal adipose tissue in early lactating cows fed CLA, which may suggest reduced lipolysis in adipose tissue. Accordingly, changes in plasmatic NEFA after a $\beta$-adrenergic challenge (epinephrine) in cows fed trans-10,cis-12 C18:2 were small (Baumgard et al., 2002; de Veth et al., 2006). However, trans-10, cis-12 C18:2 decreased adipocyte size in primiparous cows during early lactation, suggesting that CLA may stimulate adipose tissue lipolysis (Akter et al., 2011). Adipose tissue response to adrenergic challenge in cow is altered according to changes in body energy input and output (McNamara, 1988), which are affected by CLA. In dairy goats, no study has reported on the effect of trans-10,cis-12 C18:2 on reactivity of adipose tissue to lipolytic signals.

In consequence, this trial studied the long-term effect of trans-10,cis-12 C18:2 supplementation on milk performance, milk FA composition, energy metabolism, and reactivity of adipose tissue evaluated by a $\beta$-agonist challenge in early to mid-lactating goats fed a high-concentrate diet based on corn silage.

\section{MATERIALS AND METHODS}

\section{Animals and Diets}

Twenty-four multiparous dairy Saanen or Alpine goats $(\mathrm{BW}=63.7 \pm 8.0 \mathrm{~kg}, 30 \pm 4 \mathrm{DIM}$; mean $\pm \mathrm{SD})$ were used for $10 \mathrm{wk}$, with the first $3 \mathrm{wk}$ for adaptation to experimental diets. Twelve of the goats were fitted with a ruminal cannula and a T-type duodenal cannula for determination of the diet digestibility and measurement of duodenal flow (not described here) and they were housed in metabolism crates after the adaptation period. The 12 other goats were kept in individual pens. At the initiation of the trial, the average milk yield (mean $\pm \mathrm{SD}$ ) was $3.9 \pm 1.3 \mathrm{~kg} / \mathrm{d}$, with a milk fat content (mean $\pm \mathrm{SD}$ ) of $35.0 \pm 5 \mathrm{~g} / \mathrm{L}$ and a milk protein content (mean $\pm \mathrm{SD}$ ) of $32 \pm 2 \mathrm{~g} / \mathrm{L}$.

The goats were allocated to 2 groups according to their milk production and fat content measured $30 \mathrm{~d}$ after parturition. From parturition to the start of the trial (wk 0), all goats were fed ad libitum twice per day (0800 and $1700 \mathrm{~h}$ ) a TMR consisting (on a DM basis) of a mixture of grass hay (20\%), dehydrated alfalfa pellets (20\%), beet pulp (30\%), and a commercial concentrate (30\%; Fluvia Selectunic, Sanders, France). The dietary transition was made in the first week of the adaptation period for corn silage, followed by the addition of lipid supplements in the second week. Throughout the experimental period of 7 wk (wk 3 to 9), the goats were fed ad libitum a TMR containing corn silage $(35 \%$ on a DM basis), beet pulp (20\%), barley (15\%), and the same commercial concentrate $(30 \%)$. The CP, OM, NDF, ADF, and starch contents (DM basis) of the basal diet without adding either Ca salts of palm oil (control, CTL) or CLA supplement were 118, 922, 381, 188 , and $175 \mathrm{~g} / \mathrm{kg}$ of $\mathrm{DM}$, respectively. The $\mathrm{NE}_{\mathrm{L}}$ of the TMR was $1,500 \mathrm{kcal} / \mathrm{kg}$ of DM. The composition of FA of the basal diet is given in Table 1. Lipid supplements (CTL supplement vs. CLA, $45 \mathrm{~g} / \mathrm{d}$ ) were top-dressed on the TMR and thoroughly hand mixed. The CTL supplement consisted of Ca salts of palm oil (Saphir Intense; Eolia, Bruz, France). The CLA supplement (Lutrell; BASF Animal Nutrition, Château-Gontier, France) had a lipid content of $65 \%$ and a FA composition of $15 \%$ trans-10, cis- 12 C18:2, $15 \%$ cis-9,trans- 11 $\mathrm{C} 18: 2,9 \% 16: 0 ; 42 \% 18: 0,12 \%$ cis-9 $\mathrm{C} 18: 1$, and $1 \%$ cis-9, cis-12 C18:2, corresponding to a daily distribution of $4.5 \mathrm{~g}$ of cis-9,trans $-11 \mathrm{C} 18: 2 / \mathrm{d}$ and $4.5 \mathrm{~g}$ of trans10,cis-12 C18:2/d. The CTL supplement had a lipid content of $90 \%$ with $50 \%$ C16:0; $35 \%$ of $\mathrm{C} 18: 1$ cis-9, and $10 \% \mathrm{C} 18: 2$ cis-9, cis-12. Lipid supplements distribution was $15 \mathrm{~g}$ and $30 \mathrm{~g}$ in the morning and afternoon feed allocations, respectively.

\section{Experimental Measurements and Sampling}

From wk 2 onwards, feed intake was recorded daily. Three diet samples were collected at the end of the adaptation period (wk 2), in the middle (wk 6), and in wk 9 for feed composition analyses and total lipid determination. Goats were weighed once per week at the same time in the middle of the day. During the 
trial (from wk 0 to 9), 2 milk samples of $30 \mathrm{~mL}$ (one at the evening milking and one at the following morning milking) were individually collected each week with a preservative (Bronopol; Grosseron SA, Saint-Herblain, France) and stored at $4^{\circ} \mathrm{C}$ until milk composition analysis (protein, fat, and lactose content). During wk 1, 5, and 6,2 additional milk samples of $30 \mathrm{~mL}$ (one at the evening milking and one at the following morning milking) were individually collected without preservative, and stored at $-18^{\circ} \mathrm{C}$ for milk FA composition.

\section{Isoproterenol Challenges}

In the last week of the trial, an intravenous isoproterenol (ISOP) challenge was performed on the 12 cannulated goats fed the CTL or CLA diets. A solution of ISOP (Sigma-Aldrich, Saint-Quentin-Fallavier, France) of $40 \mu \mathrm{g} / \mathrm{mL}$ was prepared in $\mathrm{NaCl}(9 \%)$ the day before the challenge as described by Gagliostro and Chilliard (1991) and was kept at $4^{\circ} \mathrm{C}$. The day of challenge, the solution was heated on a hot plate agitator $\left(37^{\circ} \mathrm{C}\right)$, and a dose of $4 \mathrm{n} M \mathrm{ISO} / \mathrm{kg}$ of $\mathrm{BW}(1 \mu \mathrm{g} / \mathrm{kg}$ of BW) was injected within $15 \mathrm{~s}$ into the left jugular vein of each goat immediately after morning milking. During the challenge, the 12 goats were not fed. Blood samples were collected from the jugular vein into heparin vials at $-20,-5,+5,+10,+15,+20,+25,+30,+45$, and +60 min relative to the injection. Blood samples were immediately centrifuged at $1,780 \times g$ for $10 \mathrm{~min}$ at $4^{\circ} \mathrm{C}$ and plasma was stored at $-18^{\circ} \mathrm{C}$ until analysis for glucose, NEFA, BHBA, and insulin.

\section{Laboratory Analysis}

For each time point, 1 feed sample was dried in a forced-air oven at $90^{\circ} \mathrm{C}$ for $24 \mathrm{~h}$ to determine DM content and then ground and stored at room temperature until determination of the OM, NDF, ADF (Van Soest et al., 1991), and starch (Gluco-sequant glucose/HK; Roche/Hitachi Diagnostics, Mannheim, Germany) content. Dry matter, ash, and enzymatic starch in feed were determined following International Organization for Standardization (ISO) standards: ISO (1999; 6496), ISO $(2002 ; 5984)$, and ISO $(2004 ; 15914)$, respectively. The 2 other feed samples were immediately stored at $-20^{\circ} \mathrm{C}$ and lately lyophilized and ground for total lipid determination and FA analysis according to Folch et al., (1957).

Methyl esters from milk or feed samples were injected with an autosampler into a Varian CP 3800 gas chromatograph equipped with a flame ionization detector (Varian SA, Les Ulis, France) on a CP-Sil 88 (100-m $\times$ $0.25-\mathrm{mm}$ i.d. fused silica capillary column; Interchim, Montluçon, France). The carrier gas was ultra-pure
Table 1. Fatty acid profile and contents of the basal diet

\begin{tabular}{lc}
\hline Item & Basal diet \\
\hline FA profile, \% of total FA & \\
C14:0 & 2.23 \\
C16:0 & 23.34 \\
C18:0 & 3.79 \\
cis-9 C16:1 & 0.49 \\
cis-9 C18:1 27.41 \\
cis-9, cis-12 C18:2 12.48 \\
cis-9, cis-12,cis-15 C18:3 & 3.33 \\
FA, mg/g of DM & \\
C14:0 & 0.031 \\
C16:0 $18: 0$ & 0.324 \\
cis-9 C16:1 & 0.053 \\
cis-9 C18:1 & 0.007 \\
cis-9, cis-12 C18:2 15 - cis-12,cis-15 C18:3 & 0.381 \\
Total FA & 0.451 \\
\end{tabular}

helium with a flow of $1 \mathrm{~mL} / \mathrm{min}$. Injector and detector temperatures were maintained at $250^{\circ} \mathrm{C}$. The split ratio in the injector was 20:1. The initial oven temperature was $50^{\circ} \mathrm{C}$ (for $1 \mathrm{~min}$ ) and was then increased at $10^{\circ} \mathrm{C} /$ min to $170^{\circ} \mathrm{C}$ (held for $78 \mathrm{~min}$ ) and then increased again at $5^{\circ} \mathrm{C} / \mathrm{min}$ to $220^{\circ} \mathrm{C}$ (held for $15 \mathrm{~min}$ ). Individual FA were identified by comparison of retention time to those of pure standards (Supelco Inc., Bellefonte, PA).

For plasma glucose, NEFA, and BHBA analyses, an autoanalyzer (Cobas-Mira Roche/Hitachi, Mannheim, Germany) was used with kits (Gluco-sequant glucose/ HK, Roche/Hitachi Diagnostics; NEFA-HR(2), Wako Chemicals GmbH, Neuss, Germany). $\beta$-Hydroxybutyrate was analyzed by the method of Barnouin et al. (1986). Insulin was analyzed with an ELISA kit (10-1202-01; Mercodia AB, Uppsala, Sweden).

\section{Statistical Analysis}

Milk yield; fat, protein, and lactose yields and contents; DMI; and BW measured during the trial were evaluated using the MIXED procedure of SAS (SAS Institute Inc., Cary, NC) for repeated measures according to the following statistical model:

$$
Y_{i j k l}=\mu+A_{i}+B_{j}+A B_{i j}+C_{k}+D_{1}+\operatorname{Cov}_{1}+\varepsilon_{i j k l},
$$

where $Y_{i j k l}$ is the response variable, $\mu$ is the overall mean, $A_{i}$ is the fixed effect of treatment (CTL vs. CLA), $B_{j}$ is the fixed effect of time ( $\left.7 \mathrm{wk}\right), A B_{i j}$ is the interaction between the treatment and time, $C_{k}$ is the cannula effect (cannulated vs. intact), $\operatorname{Cov}_{1}$ is a covariate measured at the end of wk 2 , and $\varepsilon_{i j k l}$ is the residual error. Goat was considered as a random effect $\left(D_{1}\right)$. A first-order autoregressive [AR (1)] covariance structure was used for repeated measures. The same model was 
Table 2. Live BW, DMI, net energy balance, and milk production and composition in lactating goats fed $45 \mathrm{~g} / \mathrm{d}$ of Ca salts of palm oil (control, CTL) or $45 \mathrm{~g} / \mathrm{d}$ of conjugated linoleic acid (CLA; mixture of 2 isomers: trans-11,cis-9 C18:2 and trans-10, cis-12 C18:2) ${ }^{1}$

\begin{tabular}{|c|c|c|c|c|c|c|}
\hline \multirow[b]{2}{*}{ Item } & \multicolumn{2}{|c|}{ Treatment } & \multirow[b]{2}{*}{ SEM } & \multicolumn{3}{|c|}{$P$-value } \\
\hline & CTL $(\mathrm{n}=12)$ & CLA $(\mathrm{n}=12)$ & & CLA & Time $(\mathrm{T})$ & $\mathrm{CLA} \times \mathrm{T}$ \\
\hline DMI, $\mathrm{kg} / \mathrm{d}$ & 3.04 & 3.01 & 0.096 & 0.81 & $<0.0001$ & 0.71 \\
\hline Milk production, $\mathrm{kg} / \mathrm{d}$ & 3.82 & 3.74 & 0.14 & 0.18 & $<0.0001$ & 0.91 \\
\hline \multicolumn{7}{|l|}{ Milk yield, g/d } \\
\hline Fat & 175.8 & 144.7 & 7.5 & $<0.0001$ & $<0.0001$ & 0.80 \\
\hline \multicolumn{7}{|l|}{ Milk composition, g/L } \\
\hline Fat & 45.8 & 38.9 & 1.37 & $<0.0001$ & $<0.0001$ & 0.82 \\
\hline Protein & 32.1 & 31.6 & 0.53 & 0.16 & 0.28 & 0.60 \\
\hline Lactose & 48.6 & 48.8 & 0.34 & 0.44 & 0.80 & 0.91 \\
\hline Energy balance, ${ }^{2} \mathrm{kcal} / \mathrm{d}$ & -82 & 177 & 97.89 & 0.02 & 0.14 & 0.88 \\
\hline
\end{tabular}

${ }^{1}$ Values represent least squares means, with data obtained during wk 2 as covariates.

${ }^{2}$ Net energy balance during the trial $=($ net energy intake + net energy value of the CLA or Ca salt of palm oil $)-\left(\mathrm{NE}_{\mathrm{M}}+\mathrm{NE}_{\mathrm{L}}\right)$.

used to evaluate the effect of CLA, time, and CLA $\times$ time interaction on each milk FA measured during wk 5 and 6 , with wk 2 values used as a covariate. Preliminary statistical analysis showed that the cannula effect and CLA $\times$ cannula interaction effect were not significant; therefore, these effects were withdrawn from the model.

Treatment effects on plasma concentrations of NEFA, glucose, insulin, and BHBA, after ISOP injection were tested for baseline concentrations (baseline values calculated as the average at -20 and -5 min before ISOP injection), maximal concentrations (at 5 or 10 min after injection), maximal increase above basal value, changes in the area under the curve (AUC; calculated as the positive incremental area that was above baseline value during the first 25 min relative to ISOP injection), and total AUC (total AUC, calculated as the area from -20 into 25 min after injection), as described by Cardoso et al. (2011). These data were analyzed using the GLM procedure of SAS (SAS Institute Inc.) according to the following model:

$$
Y_{i j}=\mu+A_{i}+\varepsilon_{i j}
$$

where $Y_{i j}$ is the response variable, $\mu$ is the overall mean, $A_{i}$ is the fixed effect of treatment (CTL vs. CLA), and $\varepsilon_{i j}$ is the random residual error. Least squares means are reported and treatment effects are declared significant at $P<0.05$.

\section{RESULTS}

\section{Animal Performance}

The BW, DMI, milk yield, and milk protein and lactose yields and contents were unaffected by CLA (Table
2). Compared with the CTL, the CLA treatment significantly decreased milk fat yield and content by 18 and $15 \%$, respectively. The CLA treatment increased the net energy balance (NEB) by $260 \mathrm{Kcal} / \mathrm{d}$. No interactions were observed between CLA treatment and time for BW, DMI, NEB, milk yield, or milk protein and lactose yields and contents, or milk fat yield and milk fat content.

\section{Milk FA Profile}

The trans-10,cis-12 C18:2 isomer was detected only in the milk of goats fed the CLA treatment, with no change in the proportion of the cis-9,trans-11 C18:2 isomer between the groups. Apparent efficiency of transfer of trans-10, cis-12 C18:2 from diet to milk $\{100 \times[$ trans10,cis-12 C18:2 output in milk (g/d)]/[trans-10,cis-12 $\mathrm{C} 18: 2$ intake $(\mathrm{g} / \mathrm{d})]\}$ was $1.9 \%$. The interaction between the CLA treatment and time was not significant for most of milk FA. Compared with the CTL, the CLA treatment did not affect the proportions of the sums of SFA, PUFA, or FA with $\mathrm{C}<16$ in milk fat. It increased the sum of ISOP FA (Table 3). When the FA were considered individually (Appendix Table A1), the CLA treatment decreased numerically or significantly the proportions of the linear FA from $\mathrm{C} 8$ to $\mathrm{C} 13$, and $\mathrm{C} 16: 0$ in milk fat. It increased the proportions of C4:0, C14:0, C18:0, C19:0, C20:0, and C22:0. The CLA treatment did not affect the sum of trans C18:1 (Table 3), but it tended to increase the proportion of the trans-11, trans-13 + trans-14, and trans-16 isomers of C18:1. Compared with CTL, the CLA treatment reduced the sum of cis C18:1 isomers, cis-9 C18:1, and the sum of $\mathrm{C} 16: 0+$ cis-7 C16:1. It also reduced the ratios of cis5 C14:1/C14:0, cis-9 C18:1/C18:0, and cis-9,trans-11 
Table 3. Summation of some groups of milk FA (g/100 g of milk fat) in lactating goats fed $45 \mathrm{~g} / \mathrm{d}$ of Ca salts of palm oil (control, CTL) or 45 $\mathrm{g} / \mathrm{d}$ of conjugated linoleic acid (CLA; mixture of 2 isomers: trans-11,cis-9 C18:2 and trans-10,cis-12 C18:2) ${ }^{1}$

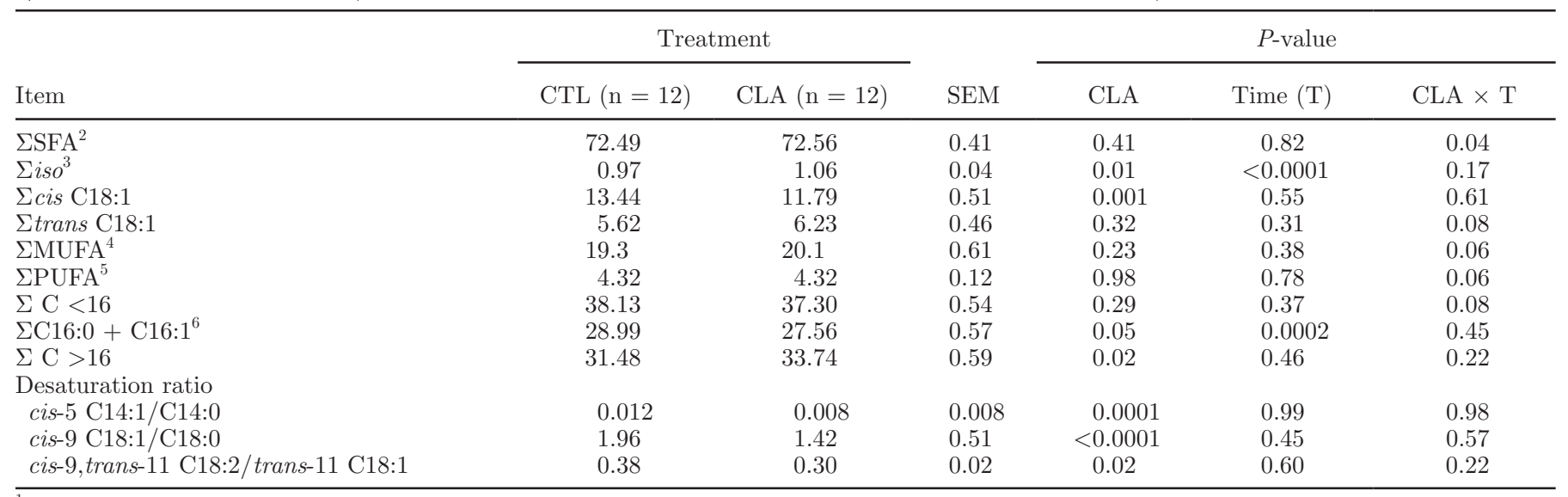

${ }^{1}$ Values presented are least squares means, with data measured during wk 2 as covariates. Full details of milk FA composition are given in the Appendix.

${ }^{2}$ Saturated FA including pair and odd FA.

${ }^{3}$ Includes iso C14:0, iso C15:0, iso C16:0, and iso C17:0.

${ }^{4}$ Monounsaturated FA $=\Sigma($ cis-5 C14:1, cis-6 C15:1, cis-7 C16:1, total cis C18:1, total trans C18:1, and cis-11 C20:1).

${ }^{5}$ Polyunsaturated FA $=\Sigma$ (all isomers of C18:2, cis-9, cis-12,cis-15 C18:3, cis-6, cis-9, cis-12 C18:3, and C20:3n-3).

${ }^{6}$ Includes anteiso C17:0.

C18:2/trans-11 C18:1 by $33.3 \% 27.6$, and $21.1 \%$ respectively. The CLA treatment increased the sum of $>\mathrm{C} 16$ FA by $7.2 \%$ (Table 3 ).

The CLA treatment significantly reduced milk secretion of $<$ C16 FA synthesized de novo (353 vs. 290 $\mathrm{mmol} / \mathrm{d}$ for CTL and CLA, respectively) and the sum of $\mathrm{C} 16: 0+$ cis-7 C16:1 (194 vs. $154 \mathrm{mmol} / \mathrm{d})$, and it

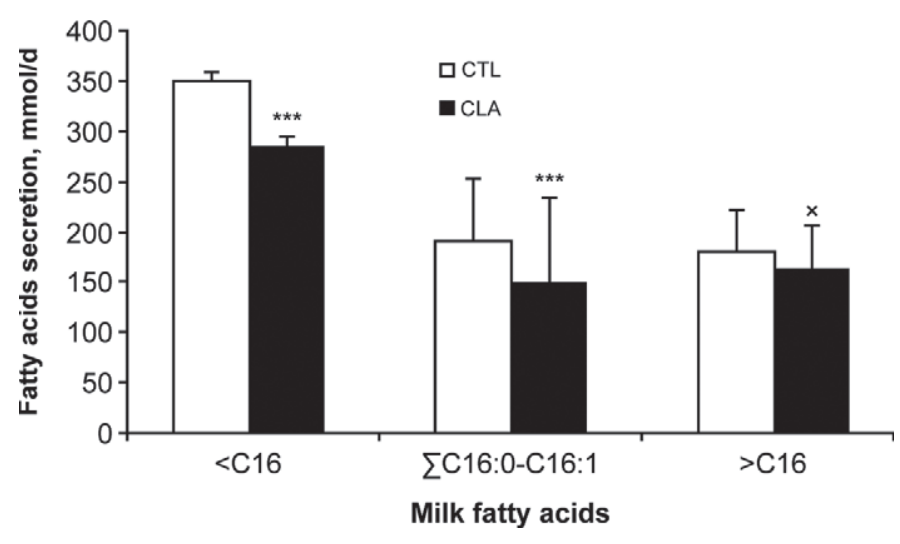

Figure 1. Milk FA secretion $(\mathrm{mmol} / \mathrm{d})$ in lactating goats fed 45 $\mathrm{g} / \mathrm{d}$ of Ca salts of palm oil (control, CTL) or $45 \mathrm{~g} / \mathrm{d}$ of conjugated linoleic acid (CLA; mixture of 2 isomers: trans-11,cis-9 C18:2 and trans10,cis-12 C18:2). Fatty acids are categorized according to metabolic origin: <C16 synthesized de novo, C16:0 + C16:1, and >C16 taken up from circulating plasma lipids. Values presented are least squares means, with data measured during wk 2 as covariates. ${ }^{*} * * P<0.001$; $\times$ indicates $P=0.07$. Error bars indicate standard deviations. tended to decrease $(P=0.07)$ the secretion of $>$ C16 FA in milk (184 vs. $164 \mathrm{mmol} / \mathrm{d}$; Figure 1).

\section{Response of Plasma Concentrations to an Isoproterenol Challenge}

Compared with CTL, the CLA treatment increased NEB by $77.5 \%$ for wk 8 , which was before ISOP challenge. Baseline plasma concentrations $(-20$ and -5 min before the ISOP challenge) of glucose, NEFA, and BHBA were not affected by CLA treatment (Table 4). The baseline concentration of insulin was numerically higher in the CLA group than in the CTL group $(P=$ 0.15). Compared with the CTL, the glucose-to-insulin ratio at baseline tended to be lower in the CLA treatment $(P=0.08)$. After ISOP challenge, concentrations of glucose, NEFA, and insulin increased for 5 or 10 min and decreased thereafter to return to baseline concentrations at 25 or 30 min (Figure 2). The maximal concentrations (peak) and the increases above basal concentrations of glucose, NEFA, and insulin were not affected by CLA treatment (Table 4). The concentration of BHBA decreased during the $60 \mathrm{~min}$ after ISOP injection.

Changes in the AUC for glucose, NEFA, BHBA, insulin, and total AUC of glucose and NEFA were not affected by CLA treatment. Total AUC of BHBA and insulin tended to be higher $(P=0.10$ and 0.13 , respectively) and the ratio of total AUC of glucose to total 
Table 4. Changes in plasma concentrations of glucose, NEFA, BHBA, and insulin to isoproterenol (ISOP) challenge (4 nmol of ISOP $/ \mathrm{kg}$ of BW) in lactating goats fed $45 \mathrm{~g} / \mathrm{d}$ of Ca salts of palm oil (control, CTL) or $45 \mathrm{~g} / \mathrm{d}$ of conjugated linoleic acid (CLA; mixture of 2 isomers: trans-11,cis-9 C18:2 and trans-10, cis-12 C18:2) ${ }^{1}$

\begin{tabular}{|c|c|c|c|c|}
\hline \multirow[b]{2}{*}{ Item } & \multicolumn{2}{|c|}{ Treatment } & \multirow[b]{2}{*}{ SEM } & \multirow{2}{*}{$\frac{P \text {-value }}{\mathrm{CLA}}$} \\
\hline & CTL $(\mathrm{n}=6)$ & CLA $(\mathrm{n}=6)$ & & \\
\hline Net energy balance, kcal/d & 373 & 662 & 148 & 0.03 \\
\hline $\mathrm{BW}, \mathrm{kg}$ & 61.63 & 62.82 & 2.93 & 0.85 \\
\hline \multicolumn{5}{|l|}{ Baseline concentration } \\
\hline Glucose, $\mathrm{g} / \mathrm{L}$ & 0.586 & 0.601 & 0.019 & 0.72 \\
\hline $\mathrm{NEFA}, \mu \mathrm{mol} / \mathrm{L}$ & 178.3 & 157.6 & 14.24 & 0.49 \\
\hline BHBA, mg/L & 42.3 & 51.1 & 3.39 & 0.21 \\
\hline Insulin, $\mu \mathrm{g} / \mathrm{L}$ & 0.236 & 0.415 & 0.06 & 0.15 \\
\hline Glucose:insulin ratio & 3.15 & 1.77 & 0.395 & 0.08 \\
\hline \multicolumn{5}{|l|}{ Maximal concentration $^{2}$} \\
\hline Glucose, $\mathrm{g} / \mathrm{L}$ & 0.729 & 0.738 & 0.019 & 0.83 \\
\hline $\mathrm{NEFA}, \mu \mathrm{mol} / \mathrm{L}$ & 311.3 & 322.3 & 21.56 & 0.81 \\
\hline $\mathrm{BHBA}, \mathrm{mg} / \mathrm{L}$ & 28.3 & 36.7 & 2.42 & 0.08 \\
\hline Insulin, $\mu \mathrm{g} / \mathrm{L}$ & 0.662 & 0.818 & 0.072 & 0.30 \\
\hline \multicolumn{5}{|l|}{ Increase above basal value } \\
\hline Glucose, $\mathrm{g} / \mathrm{L}$ & 0.128 & 0.151 & 0.020 & 0.58 \\
\hline $\mathrm{NEFA}, \mu \mathrm{mol} / \mathrm{L}$ & 133.1 & 164.8 & 13.5 & 0.26 \\
\hline $\mathrm{BHBA}, \mathrm{mg} / \mathrm{L}$ & -14.1 & -14.4 & 1.69 & 0.91 \\
\hline Insulin, $\mu \mathrm{g} / \mathrm{L}$ & 0.426 & 0.403 & 0.034 & 0.76 \\
\hline \multicolumn{5}{|l|}{ Changes in $\mathrm{AUC}^{3}$} \\
\hline Glucose, $\mathrm{mg} / \mathrm{L} \times 25 \mathrm{~min}$ & 1.76 & 2.65 & 0.42 & 0.31 \\
\hline NEFA, $\mu \mathrm{mol} / \mathrm{L} \times 25 \mathrm{~min}$ & $1,019.4$ & $1,416.5$ & 174.3 & 0.27 \\
\hline $\mathrm{BHBA}, \mathrm{mg} / \mathrm{L} \times 25 \mathrm{~min}$ & -162.5 & -121.2 & 31.07 & 0.53 \\
\hline Insulin, $\mu \mathrm{g} / \mathrm{L} \times 25 \mathrm{~min}$ & 5.02 & 4.74 & 0.87 & 0.88 \\
\hline \multicolumn{5}{|l|}{ Total AUC } \\
\hline Glucose, $\mathrm{mg} / \mathrm{L} \times 25 \mathrm{~min}$ & 29.1 & 29.4 & 0.02 & 0.86 \\
\hline $\mathrm{NEFA}, \mu \mathrm{mol} / \mathrm{L} \times 25 \mathrm{~min}$ & 9,435 & 8,948 & 684 & 0.74 \\
\hline $\mathrm{BHBA}, \mathrm{mg} / \mathrm{L} \times 25 \mathrm{~min}$ & 1,723 & 2,160 & 133 & 0.10 \\
\hline Insulin, $\mu \mathrm{g} / \mathrm{L} \times 25 \mathrm{~min}$ & 17 & 24 & 2.4 & 0.13 \\
\hline Glucose:insulin ratio, ${ }^{5} \times 25 \mathrm{~min}$ & 1.88 & 1.38 & 0.16 & 0.11 \\
\hline
\end{tabular}

${ }^{1}$ Values represent mean response to ISOP (4 nmol of ISOP $/ \mathrm{kg}$ of BW) challenge.

${ }^{2}$ The maximal value was observed at 5 or 10 min after the ISOP injection.

${ }^{3}$ Area under the curve (AUC) was calculated as the positive incremental area that was above baseline value during the first 25 min after injection.

${ }^{4}$ Total AUC was calculated as the area from -20 into 25 min relative to ISOP injection.

${ }^{5}$ Ratio of total AUC of glucose:total AUC of insulin (between -20 and +25 min relative to ISOP injection).

AUC of insulin tended to be lower $(P=0.11)$ in the CLA group compared with the CTL (Table 4).

\section{DISCUSSION}

\section{Animal Performance}

Compared with cows (reviewed by Harvatine et al., 2009; Bauman et al., 2011), dietary CLA have been less used in dairy goats (Erasmus et al., 2004; Lock et al., 2008; Shingfield et al., 2009). Our data confirm previous conclusions demonstrating that milk fat yield is reduced after CLA supplementation in goats but that goats appear less sensitive to CLA than cows (Shingfield et al., 2009). Indeed, we obtained a mean proportion of $0.10 \%$ trans-10,cis-12 C18:2 in milk fat that decreased MFC by $15 \%$ and fat yield by $18 \%$. In comparison, a similar proportion of trans-10,cis-12 C18:2 in milk induced a decrease in milk fat content and in milk yield between 25 and $30 \%$ in cows (Perfield et al., 2004; Moore et al., 2005). Moreover, temporal patterns of decrease in MFC are different between goats and cows, as the response to CLA is obtained within 2 to $3 \mathrm{~d}$ in cows, whereas we found it takes at least $7 \mathrm{~d}$ in goats (see also Lock et al., 2008).

In our experiment, the decrease in milk fat content and fat yield were intermediary to those previously reported in goats (Lock et al., 2008; Shingfield et al., 2009). The main difference in response is largely related to the trans-10,cis-12 C18:2 intake and its bioavailability. Using a dose ranging from 7 to $22 \mathrm{~g}$ of trans10,cis-12 C18:2/d (Shingfield et al., 2009) and from 3 to $6 \mathrm{~g} / \mathrm{d}$ (Lock et al., 2008), respectively, the mean concentration of trans-10, cis-12 C18:2 in milk ranged from 0.2 to $0.8 \%$, and from 0.1 to $0.2 \%$ respectively. In those studies, the calculated transfer efficiency of di- 

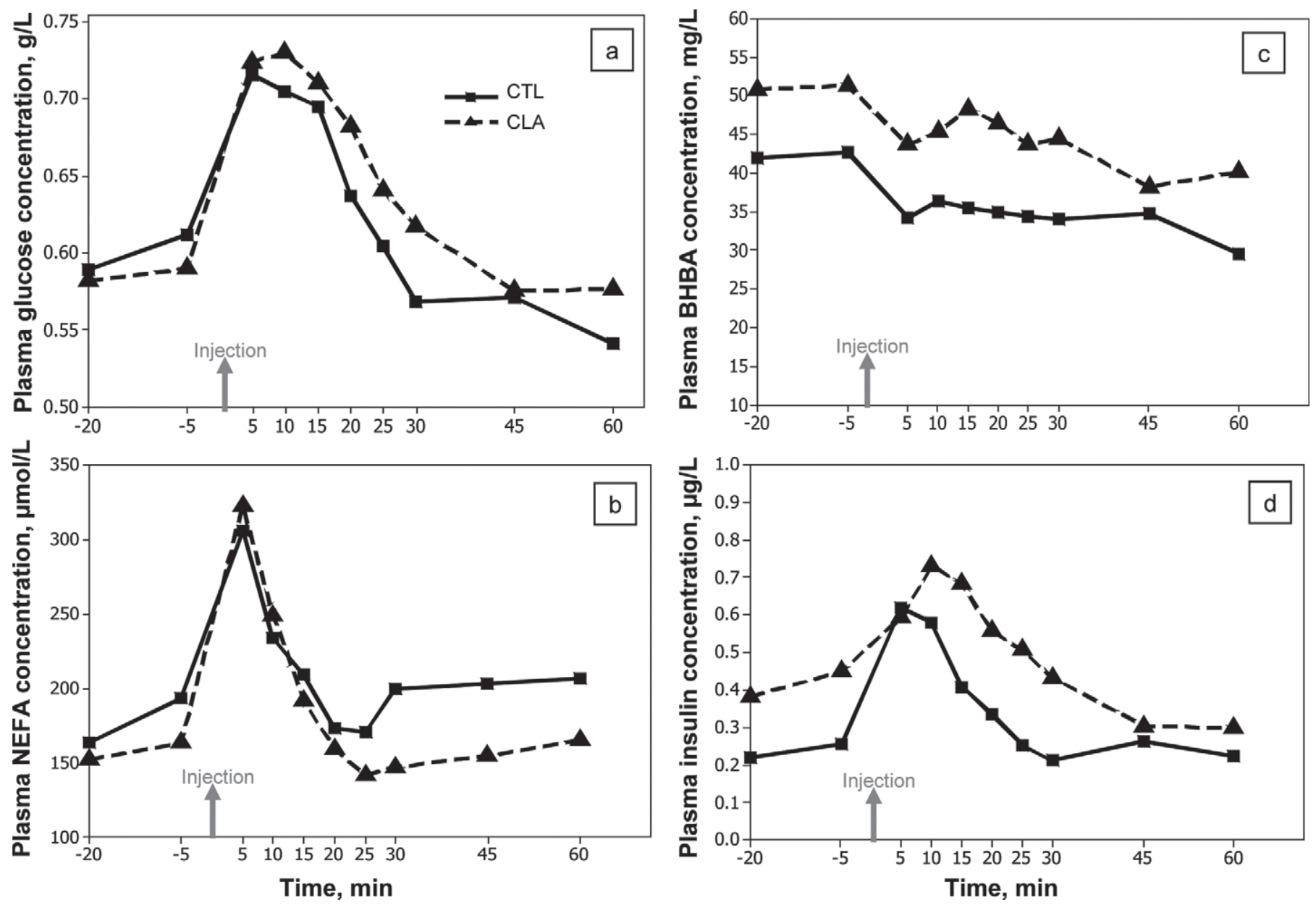

Figure 2. Mean plasma concentrations (a: glucose, b: NEFA, c: BHBA, and d: insulin) in response to isoproterenol challenge (4 nmol/kg of BW) in lactating goats fed $45 \mathrm{~g} / \mathrm{d}$ of Ca salts of palm oil (control, CTL) or $45 \mathrm{~g} / \mathrm{d}$ of conjugated linoleic acid (CLA; mixture of 2 isomers: trans11,cis-9 C18:2 and trans-10,cis-12 C18:2). Standard errors of the means for glucose, NEFA, BHBA, and insulin were 0.014 g/L, $16.82 \mu \mathrm{mol} / \mathrm{L}$, $2.65 \mathrm{mg} / \mathrm{L}$, and $0.086 \mu \mathrm{g} / \mathrm{L}$, respectively.

etary trans-10,cis-12 C18:2 to milk was between 1.7 and $2.4 \%$ (Shingfield et al., 2009) and between 1.8 and $1.9 \%$ (Lock et al., 2008). This was in line with the value in the present study (1.9\%). The corresponding decreases in MFC were 25 to $36 \%$ and 5 to $18 \%$ for Shingfield et al. (2009) and Lock et al. (2008), respectively. The intake of $4.5 \mathrm{~g}$ of trans-10, cis-12 C18:2/d in our experiment produced a $15 \%$ decrease in MFC. However, closer comparison with the results of Lock et al. (2008) shows that at a similar trans-10,cis-12 proportion in milk, we obtained a greater decrease in MFC and in fat yield. This suggests that CLA-induced decrease in MFC is affected by the initial level of milk fat $(31.2 \mathrm{~g} / \mathrm{L}$ in Lock et al., 2008 vs. $45 \mathrm{~g} / \mathrm{L}$ in our trial). In line with this, at similar levels of trans-10,cis-12 C18:2 intake, the decrease in milk fat was greater in goats fed supplements of FA than those fed no lipid supplement (Shingfield et al., 2009). Similarly, the response of MFC to
CLA was less pronounced in cows exhibiting low initial MFC than those with high MFC (i.e., when cows were fed high-concentrate compared with low-concentrate diets; Glasser et al., 2010). In our conditions, a highconcentrate diet based on corn silage led to high MFC and it elicited a significant decrease in MFC in goats fed low doses of trans-10, cis-12 C18:2.

Our results also show that supplementation with 4.5 g of trans-10,cis-12 C18:2/d in lactating goats fed a high-concentrate diet based on corn silage had no effect on DMI, BW, milk yield, or milk protein and lactose yields and contents throughout a 7 -wk trial. This agrees with data in goats supplemented with a wide range of doses of trans-10,cis-12 C18:2 and fed alfalfa or corn silage diets with 35 to $60 \%$ concentrate (Lock et al., 2008; Shingfield et al., 2009).

Because CLA treatment induced a decrease in the net energy needs due to a reduction in milk fat secre- 
tion (at constant DMI, BW, and milk yield relative to the CTL), CLA supplementation gradually increased net energy balance. We observed a mean increase in NEB of $260 \mathrm{Kcal} / \mathrm{d}$ between CLA and CTL treatments, larger than the calculated increase in NEB of 60 of Lock et al. (2008) and $90 \mathrm{Kcal} / \mathrm{d}$ of Shingfield et al. (2009). These differences may be related to the fact that the above-mentioned studies in goats were conducted during late lactation (140 to $250 \mathrm{~d}$ postpartum), which can affect the CLA-induced changes in partitioning of energy nutrients away from mammary gland (Gervais et al., 2005).

\section{Response to an Isoproterenol Challenge}

Before ISOP injection, plasma NEFA concentrations were not affected by CLA treatment, as reported in cows in positive energy balance or during established lactation (Baumgard et al., 2002; de Veth et al., 2006). Plasma NEFA concentration is an index of basal fat mobilization that reflects the apparent balance between basal lipolysis of triglyceride and FA esterification rate or de novo lipogenesis in adipose tissue. These processes are known to be regulated by insulin that decreases lipolysis and increases reesterification and de novo lipogenesis (Brockman and Laarveld, 1986). Insulin may control NEFA appearance through enhanced trapping into the adipose tissue of NEFA derived from intravascular triglyceride lipolysis (Carpentier et al., 2005). Conversely to data in dairy cows where no change in plasma insulin concentration were reported after CLA treatment (de Veth et al., 2006; Kay et al., 2006), we observed a trend for plasma insulin and insulin:glucose ratio to be higher in goats fed CLA, probably reflecting their higher NEB balance compared with CTL goats at this time. In dairy cows, the expression of lipogenic enzymes and of genes related to lipid synthesis in subcutaneous adipose tissue was increased during short-term trans-10,cis-12 C18:2 supplementation (Harvatine et al., 2009), reflecting the partitioning of spared energy away from milk toward adipose tissue. To date, no data are available reporting the effect of CLA on lipogenesis in adipose tissue of goats.

As no data are available on the measurement of lipolysis in adipose tissue of goats fed trans-10, cis-12 C18:2, we attempted to determine if $\beta$-agonist-stimulated lipolysis may have been enhanced by CLA supplementation. Isoproterenol is a synthetic catecholamine that is a lipolytic agent that stimulates both $\beta 1$ - and $\beta 2$ adrenergic receptors on adipocytes (Lafontan, 2008). Thus, the NEFA response to ISOP provides an efficient method of studying the adipose tissue lipolytic potential because it induces an increase in plasma NEFA concentration, which reflects the lipolytic properties of this $\beta$-agonist minus the fraction of released NEFA that is directly reesterified (Chilliard et al., 1998). The response to a $\beta$-agonist injection (norepinephrine) is unchanged in dairy cows fed CLA and a low-ME diet during midlactation (de Veth et al., 2006) or eventually reduced in dairy cows in positive net energy balance after CLA supplementation (Baumgard et al., 2002). In our study, no change in any of the parameters of NEFA response was observed after CLA treatment, as observed in cows (de Veth et al., 2006).

Before ISOP injection, plasma glucose concentration was not affected by CLA treatment, as observed in cows (Baumgard et al., 2002; de Veth et al., 2006). In the present study, glucose concentration increased rapidly after ISOP injection, probably because of its effects on liver glycogenolysis (Drackley et al., 2001) and possibly on liver gluconeogenesis (Faulkner and Pollock, 1990). This increase in glucose was also associated with an increase in insulin, with a maximal response at $10 \mathrm{~min}$ relative to ISOP injection, which is probably due to pancreas stimulation of insulin synthesis by glucose (Brockman and Laarveld, 1986; Oda et al., 1986). Nevertheless, this increase in glucose and insulin concentration after the ISOP challenge was not affected by CLA treatment in our study. The changes in AUC above baseline value and total AUC of glucose remained unaffected by CLA treatment. Nevertheless, total AUC of insulin tended to be higher and the total AUC of glucose-to-total AUC of insulin ratio tended to be lower in the CLA treatment, which may suggest increased pancreas sensitivity to hyperglycemia induced by ISOP. It is plausible that energy spared through the effects of CLA on milk energy output could affect the pancreas sensitivity to glucose to favor an increase in body fat lipogenesis (Harvatine et al., 2009).

\section{Milk FA Secretion and Profile}

The reduction in fat yield in our experiment was due to the simultaneous decrease in the mammary secretion of $<\mathrm{C} 16 \mathrm{FA}(-18 \%), \mathrm{C} 16 \mathrm{FA}(-20 \%)$, and to a lesser extent, a decrease in $>$ C16 FA secretion $(-11 \%)$. This reflects a CLA-coordinated downregulation of mRNA expression of lipogenic enzymes and enzymes of lipid metabolism in the mammary gland, implicating a role for sterol response element-binding protein 1 and Spot 14 at the cellular signaling level (Bauman et al., 2011). Generally, the decrease in FA secretion is greater for short-chain and medium-chain FA than for long-chain FA, leading to a higher proportion of long-chain FA in the milk fat of cows (Maxin et al., 2011) and of sheep (Sinclair et al., 2010). Our results are in agree- 
ment with these data, as CLA decreased the secretion of all FA, whatever their chain-length, but long-chain FA secretion was less reduced, which resulted in higher proportion of $>\mathrm{C} 16 \mathrm{FA}$ in milk fat.

However, some differences existed between our results and those previously reported in goats. With a similar concentration of trans-10,cis-12 C18:2 in goat milk, Lock et al. (2008) reported a smaller reduction in the secretion of short-chain FA and total C16 FA, and similar reductions as in our experiment were reported only with higher trans-10, cis-12 C18:2 proportion (0.3\% of total FA; Shingfield et al., 2009). Moreover, >C16 FA secretion was not reduced, whatever the dose of trans-10,cis-12 C18:2 in diet in the study of Shingfield et al. (2009), and it was significantly reduced only at a high trans-10,cis-12 C18:2 concentration in milk in the study of Lock et al. (2008). Differences in lactation stage and in duration of supplementation could explain these between-experiment differences (Bauman et al., 2008). The difference in $>$ C16 FA secretion may reflect changes in lipoprotein lipase (LPL) activity or synthesis that are differentially affected by stage of lactation, energy balance, and dietary factors (Bernard et al., 2008), as mammary LPL activity is high during midlactation and it decreased during late lactation in goats (Chilliard et al., 2003). This suggests that the ability of CLA to decrease the expression of genes involved in mammary uptake (LPL) is more effective during established lactation than during late lactation in dairy goats.

Among long-chain FA, our results are in agreement with those of Shingfield et al. (2009) and Lock et al. (2008) who reported that the reduction in milk fat synthesis in goats was associated with a decrease in the proportions of total cis $\mathrm{C} 18: 1$ and an increase in those of C18:0 and total trans C18:1. However, in our study, the increase in total trans C18:1 was not significant, reflecting only small changes in individual isomers of trans C18:1, except for an increase in trans-11 C18:1 proportion. This differs from most reports in dairy cows and goats where trans C18:1 were generally increased. Among cis C18:1 FA, only the proportion of the cis-9 isomer was reduced, which indicates a decrease in the activity of the mammary stearoyl-CoA desaturase as reflected first by the increase in C18:0 and second by the decrease in the calculated desaturase indices ratios that are a proxy of the stearoyl-CoA desaturase activity. Reductions in mammary desaturase indices have been reported with high doses of CLA in lactating cows (Peterson et al., 2004) and sheep (Sinclair et al., 2010), but not at low dosage (Maxin et al., 2011), although this is not a prerequisite for the decrease in milk fat yield (Peterson et al., 2004; de Andrade and Schmidely, 2006).

\section{CONCLUSIONS}

Conjugated linoleic acid supplementation (45 g/d) in goats fed a high-concentrate diet based on corn silage had no effect on DMI, BW, milk yield, or milk protein and lactose yields and contents, but it increased NEB. Conjugated linoleic acid supplementation significantly decreased milk fat content and yield, the secretion of short-chain and medium-chain FA, and to a lesser extent, the secretion of long-chain FA. In goats that had adequate energy intake in midlactation, the response of adipose tissue to an ISOP challenge was unaltered by CLA.

\section{ACKNOWLEDGMENTS}

We are grateful to J. Teissier (INRA, UMR791 Modélisation Systémique Appliquée aux Ruminants, Paris, France) and his team for obtaining research data on goats. We thank O. Dhumez, F. Ternois, and L. Péricard (all of INRA, UMR791) for the analysis of the samples.

\section{REFERENCES}

Akter, S. H., S. Haussler, S. Dänicke, U. Muller, D. von Soosten, J. Rehage, and H. Sauerwein. 2011. Physiological and conjugated linoleic acid-induced changes of adipocyte size in different fat depots of dairy cows during early lactation. J. Dairy Sci. 94:2871-2882.

Barnouin, J., N. el Idilbi, Y. Chilliard, J. P. Chacornac, and R. Lefaivre. 1986. Automated micro-determination of bovine plasma 3-hydroxybutyrate without deproteinization. Ann. Rech. Vet. 17:129-139.

Bauman, D. E., B. A. Corl, and D. G. Peterson. 2003. The biology of conjugated linoleic acids in ruminants. Pages 146-173 in Advances in Conjugated Linoleic Acid Research, Volume 2. J.-L. Sébédio, W. W. Christie, and R. Adlof, ed. AOCS Publishing, Urbana, IL.

Bauman, D. E., K. J. Harvatine, and A. L. Lock. 2011. Nutrigenomics, rumen-derived bioactive fatty acids, and the regulation of milk fat synthesis. Annu. Rev. Nutr. 31:299-319.

Bauman, D. E., J. W. Perfield II, K. J. Harvatine, and L. H. Baumgard. 2008. Regulation of fat synthesis by conjugated linoleic acid: Lactation and the ruminant model. J. Nutr. 138:403-409.

Baumgard, L. H., B. A. Corl, D. A. Dwyer, A. Sæbø, and D. E. Bauman. 2000. Identification of the conjugated linoleic acid isomer that inhibits milk fat synthesis. Am. J. Physiol. Regul. Integr. Comp. Physiol. 278:R179-R184.

Baumgard, L. H., E. Matitashvili, B. A. Corl, D. A. Dwyer, and D. E. Bauman. 2002. trans-10, cis-12 Conjugated Linoleic Acid decreases lipogenic rates and expression of genes involved in milk lipid synthesis in dairy cows. J. Dairy Sci. 85:2155-2163.

Bernard, L., C. Leroux, and Y. Chilliard. 2008. Expression and nutritional regulation of lipogenic genes in the ruminant lactating mammary gland. Adv. Exp. Med. Biol. 606:67-108.

Brockman, R. P., and B. Laarveld. 1986. Hormonal regulation of metabolism in ruminants; a review. Livest. Prod. Sci. 14:313-334.

Cardoso, F. C., W. Sears, S. J. LeBlanc, and J. K. Drackley. 2011. Technical note: Comparison of 3 methods for analyzing areas under the curve for glucose and nonesterified fatty acids concentrations following epinephrine challenge in dairy cows. J. Dairy Sci. 94:6111-6115.

Carpentier, A. C., F. Frisch, D. Cyr, P. Généreux, B. W. Patterson, R. Giguère, and J.-P. Baillargeon. 2005. On the suppression of plasma nonesterified fatty acids by insulin during enhanced intra- 
vascular lipolysis in humans. Am. J. Physiol. Endocrinol. Metab. 289:E849-E856.

Chilliard, Y., A. Ferlay, L. Despres, and F. Bocquier. 1998. Plasma non-esterified fatty acid response to a beta-adrenergic challenge before or after feeding in energy underfed or overfed, dry or lactating cows. Anim. Sci. 67:213-223.

Chilliard, Y., A. Ferlay, J. Rouel, and G. Lamberet. 2003. A review of nutritional and physiological factors affecting goat milk lipid synthesis and lipolysis. J. Dairy Sci. 86:1751-1770.

de Andrade, P. V. D., and P. Schmidely. 2006. Effect of duodenal infusion of trans10,cis12-CLA on milk performance and milk fatty acid profile in dairy goats fed high or low concentrate diet in combination with rolled canola seed. Reprod. Nutr. Dev. 46:31-48.

de Veth, M. J., E. Castañeda-Gutiérrez, D. A. Dwyer, A. M. Pfeiffer, D. E. Putnam, and D. E. Bauman. 2006. Response to conjugated linoleic acid in dairy cows differing in energy and protein status. J. Dairy Sci. 89:4620-4631.

Drackley, J. K., T. R. Overton, and G. N. Douglas. 2001. Adaptations of glucose and long-chain fatty acid metabolism in liver of dairy cows during the periparturient period. J. Dairy Sci. 84(E. Suppl.):E100-E112.

Erasmus, L. J., Z. Bester, T. Fourie, R. J. Coertze, and L. Hall. 2004 Effect of level of rumen protected CLA supplementation on milk yield and composition in Saanen goats. S. Afr. J. Anim. Sci. 34:42-45.

Faulkner, A., and H. T. Pollock. 1990. Effects of glucagon and alphaagonists and beta-agonists on glycogenolysis and gluconeogenesis in isolated ovine hepatocytes. Biochim. Biophys. Acta 1052:229234.

Folch, J., M. Lees, and G. H. S. Stanley. 1957. A simple method for the isolation and purification of total lipids from animal tissues. J. Biol. Chem. 226:497-509.

Gagliostro, G., and Y. Chilliard. 1991. Duodenal rapeseed oil infusion in early and midlactation cows. 4 . In vivo and in vitro adipose tissue lipolytic responses. J. Dairy Sci. 74:1830-1843.

Gervais, R., R. Spratt, M. Leonard, and R. Y. Chouinard. 2005. Lactation response of cows to different levels of ruminally inert conjugated linoleic acids under commercial conditions. Can. J. Anim. Sci. 85:231-242

Glasser, F., A. Ferlay, M. Doreau, J. J. Loor, and Y. Chilliard. 2010. $t 10, c 12$-18:2-induced milk fat depression is less pronounced in cows fed high-concentrate diets. Lipids 45:877-887.

Harvatine, K. J., J. W. Perfield II, and D. E. Bauman. 2009. Expression of enzymes and key regulators of lipid synthesis is upregulated in adipose tissue during CLA-induced milk fat depression in dairy cows. J. Nutr. 139:849-854.

ISO (International Organisation for Standardization). 1999. Animal feeding stuffs - Determination of moisture and other volatile matter content. ISO 6496. ISO, Geneva, Switzerland.

ISO (International Organisation for Standardization). 2002. Animal feeding stuffs - Determination of crude ash. ISO 5984. ISO, Geneva, Switzerland.

ISO (International Organisation for Standardization). 2004. Animal feeding stuffs - Enzymatic determination of total starch content. ISO 15914. ISO, Geneva, Switzerland.

Kay, J. K., J. R. Roche, C. E. Moore, and L. H. Baumgard. 2006. Effects of dietary conjugated linoleic acid on production and metabolic parameters in transition dairy cows grazing fresh pasture. J. Dairy Res. 73:367-377.

Lafontan, M. 2008. Advances in adipose tissue metabolism. Int. J. Obes. (Lond.) 32:S39-S51.
Lock, A. L., M. Rovai, T. A. Gipson, M. J. de Veth, and D. E. Bauman. 2008. A conjugated linoleic acid supplement containing trans-10, cis-12 conjugated linoleic acid reduces milk fat synthesis in lactating goats. J. Dairy Sci. 91:3291-3299.

Lourenço, M., E. Ramos-Morales, and R. J. Wallace. 2010. The role of microbes in rumen lipolysis and biohydrogenation and their manipulation. Animal 4:1008-1023.

Maxin, G., F. Glasser, C. Hurtaud, J. L. Peyraud, and H. Rulquin. 2011. Combined effects of trans-10,cis-12 conjugated linoleic acid, propionate, and acetate on milk fat yield and composition in dairy cows. J. Dairy Sci. 94:2051-2059.

McNamara, J. P. 1988. Regulation of bovine adipose tissue metabolism during lactation. 4. Dose- responsiveness to epinephrine as altered by stage of lactation. J. Dairy Sci. 71:643-649.

Moore, C. E., J. K. Kay, R. J. Collier, M. J. VanBaale, and L. H. Baumgard. 2005. Effect of supplemental conjugated linoleic acids on heat-stressed Brown Swiss and Holstein cows. J. Dairy Sci. 88:1732-1740.

Oda, S., Y. Ohtomo, A. Ohneda, Y. Sasaki, and T. Tsuda. 1986. Adrenergic modulation of pancreatic glucagon and insulin secretion in goats. Comp. Biochem. Physiol. A Comp. Physiol. 84:723-728.

Perfield, J. W., II, A. L. Lock, J. M. Griinari, A. Sæbø, P. Delmonte, D. A. Dwyer, and D. E. Bauman. 2007. Trans-9, cis-11 conjugated linoleic acid reduces milk fat synthesis in lactating dairy cows. J. Dairy Sci. 90:2211-2218.

Perfield, J. W., II, A. Sæbø, and D. E. Bauman. 2004. Use of conjugated linoleic acid (CLA) enrichments to examine the effects of trans-8, cis-10 CLA, and cis-11, trans-13 CLA on milk-fat synthesis. J. Dairy Sci. 87:1196-1202.

Peterson, D. G., E. A. Matitashvili, and D. E. Bauman. 2004. The inhibitory effect of trans-10, cis-12 CLA on lipid synthesis in bovine mammary epithelial cells involves reduced proteolytic activation of the transcription factor SREBP-1. J. Nutr. 134:2523-2527.

Sæbø, A., J. W. Perfield II, P. Delmonte, M. P. Yurawecz, P. Lawrence, J. T. Brenna, and D. E. Bauman. 2005. Milk fat synthesis is unaffected by abomasal infusion of the conjugated diene 18:3 isomers cis-6,trans-10,cis-12 and cis-6,trans-8,cis-12. Lipids 40:89-95.

Shingfield, K. J., L. Bernard, C. Leroux, and Y. Chilliard. 2010. Role of trans fatty acids in the nutritional regulation of mammary lipogenesis in ruminants. Animal 4:1140-1166.

Shingfield, K. J., J. Rouel, and Y. Chilliard. 2009. Effect of calcium salts of a mixture of conjugated linoleic acids containing trans-10, cis-12 in the diet on milk fat synthesis in goats. Br. J. Nutr. 101:1006-1019.

Sinclair, L. A., W. Weerasinghe, R. C. Wilkinson, M. J. de Veth, and D. E. Bauman. 2010. A supplement containing trans-10, cis-12 conjugated linoleic acid reduces milk fat yield but does not alter organ weight or body fat deposition in lactating ewes. J. Nutr. 140:1949-1955.

Van Soest, P. J., J. B. Robertson, and B. A. Lewis. 1991. Methods for dietary fiber, neutral detergent fiber, and non starch polysaccharides in relation to animal nutrition. J. Dairy Sci. 74:3583-3597.

von Soosten, D., U. Meyer, E. M. Weber, J. Rehage, G. Flachowsky, and S. Dänicke. 2011. Effect of trans-10, cis-12 conjugated linoleic acid on performance, adipose depot weights, and liver weight in early-lactation dairy cows. J. Dairy Sci. 94:2859-2870.

Weerasinghe, W. M. P. B., R. G. Wilkinson, A. L. Lock, M. J. de Veth, D. E. Bauman, and L. A. Sinclair. 2012. Effect of a supplement containing trans-10,cis-12 conjugated linoleic acid on the performance of dairy ewes fed 2 levels of metabolizable protein and at a restricted energy intake. J. Dairy Sci. 95:109-116. 
APPENDIX

Table A1. Milk FA composition (g/100 g of milk fat) in lactating goats fed $45 \mathrm{~g} / \mathrm{d}$ of Ca salts of palm oil (control, CTL) or $45 \mathrm{~g} / \mathrm{d}$ of conjugated linoleic acid (CLA; mixture of 2 isomers: trans-11,cis-9 C18:2 and trans-10,cis-12 C8:2)

\begin{tabular}{|c|c|c|c|c|c|c|}
\hline Item & \multicolumn{2}{|c|}{ Treatment } & SEM & \multicolumn{3}{|c|}{$P$-value } \\
\hline $\mathrm{C} 4: 0$ & 2.24 & 2.52 & 0.08 & 0.03 & 0.39 & 0.12 \\
\hline C8:0 & 3.55 & 3.27 & 0.11 & 0.001 & 0.71 & 0.27 \\
\hline C10:0 & 12.27 & 11.26 & 0.36 & 0.005 & 0.27 & 0.16 \\
\hline C11:0 & 0.31 & 0.22 & 0.02 & 0.001 & 0.33 & 0.29 \\
\hline C14:0 & 9.56 & 10.56 & 0.18 & 0.006 & 0.13 & 0.98 \\
\hline C15:0 & 0.83 & 0.88 & 0.03 & 0.21 & 0.76 & 0.39 \\
\hline C16:0 & 27.99 & 26.59 & 0.79 & 0.05 & 0.005 & 0.55 \\
\hline C17:0 & 0.60 & 0.62 & 0.02 & 0.31 & 0.27 & 0.66 \\
\hline C18:0 & 6.55 & 9.45 & 0.35 & $<0.0001$ & 0.11 & 0.37 \\
\hline C19:0 & 0.13 & 0.15 & 0.03 & 0.02 & 0.07 & 0.92 \\
\hline C20:0 & 0.11 & 0.13 & 0.005 & 0.0003 & 0.35 & 0.04 \\
\hline cis-9 C18:1 & 12.54 & 10.93 & 0.02 & 0.001 & 0.43 & 0.68 \\
\hline cis-11 C18:1 & 0.45 & 0.44 & 0.02 & 0.39 & 0.39 & 0.09 \\
\hline cis-12 C18:1 & 0.28 & 0.28 & 0.005 & 0.78 & 0.84 & 0.82 \\
\hline cis-13 C18:1 & 0.10 & 0.10 & 0.01 & 0.54 & $<0.0001$ & 0.44 \\
\hline cis-15 C18:1 & 0.06 & 0.06 & 0.005 & 0.54 & $<0.0001$ & 0.35 \\
\hline trans-4 C18:1 & 0.04 & 0.04 & 0.002 & 0.30 & 0.79 & 0.54 \\
\hline trans-5 C18:1 & 0.04 & 0.04 & 0.02 & 0.32 & 0.11 & 0.80 \\
\hline trans- $6,-7,-8$ C18:1 & 0.39 & 0.40 & 0.01 & 0.72 & 0.54 & 0.39 \\
\hline trans-9 C18:1 & 0.31 & 0.32 & 0.12 & 0.88 & $<0.0001$ & 0.17 \\
\hline trans-10 C18:1 & 0.93 & 0.60 & 0.29 & 0.17 & 0.94 & 0.52 \\
\hline trans-11 C18:1 & 2.56 & 3.52 & 0.009 & 0.06 & 0.68 & 0.17 \\
\hline trans-12 C18:1 & 0.35 & 0.38 & 0.04 & 0.11 & 0.96 & 0.58 \\
\hline trans-13,-14 C18:1 & 0.43 & 0.50 & 0.45 & 0.06 & 0.0005 & 0.91 \\
\hline trans-15 C18:1 & 0.32 & 0.33 & 0.01 & 0.45 & 0.46 & 0.30 \\
\hline cis-11 C20:1 & 0.06 & 0.06 & 0.06 & 0.46 & 0.0003 & 0.93 \\
\hline C20:3n-3 & 0.10 & 0.08 & 0.082 & 0.007 & 0.003 & 0.98 \\
\hline
\end{tabular}

${ }^{1}$ Values presented are least squares means, with data measured during wk 2 as covariates.

${ }^{2} \mathrm{ND}=$ not detected. 